Original article

\title{
ALLELIC POLYMORPHISM OF INSULIN-LIKE GROWTH FACTOR I GENE AND ITS ASSOCIATION WITH PRODUCTION TRAITS IN NATIVE CHICKENS
}

\author{
A. ESMAILNEJAD ${ }^{1} \&$ G. NIKBAKHT BRUJENI ${ }^{2}$ \\ ${ }^{1}$ Department of Pathobiology, School of Veterinary Medicine, Shiraz \\ University, Shiraz, Iran; ${ }^{2}$ Department of Microbiology and Immunology, \\ Faculty of Veterinary Medicine, University of Tehran, Tehran, Iran
}

\section{Summary}

Esmailnejad, A. \& G. Nikbakht Brujeni, 2018. Allelic polymorphism of insulin-like growth factor I gene and its association with production traits in native chickens. Bulg. J. Vet. Med., 21, No 3, 279-285.

\begin{abstract}
Insulin-like growth factor 1 (IGFI) is an essential regulator of growth, cell proliferation/differentiation and protein synthesis in a variety of cell types. IGFI is considered as one of the most important candidate genes controlling production and reproduction traits in chickens. This locus could be linked to the highly effective genes affecting egg production and growth traits. The aim of present study was to investigate the $I G F I$ gene polymorphism and its association with growth and egg production traits in Iranian native chicken. A total of 313 blood samples were collected from the Native poultry breeding centre, Khorasan province, Iran. Single nucleotide polymorphism (SNP) of the IGFI 5'-UTR was detected by PCR-RFLP method and PstI restriction endonuclease enzyme. Finally, the SNP was confirmed by sequencing of RFLP profiles. Association between $I G F I$ alleles and production traits was evaluated using multivariate regression analysis and GLM procedures. Two alleles A (PstI - ) and B $(\mathrm{PstI}+)$ and three genotypes $(\mathrm{A} / \mathrm{A}, \mathrm{A} / \mathrm{B}$ and $\mathrm{B} / \mathrm{B})$ were identified for the $I G F I$ gene. Allele $\mathrm{B}$ was the most frequent $(60.1 \%)$ and considered as reference allele for association study. A/B genotype was significantly correlated with lower first egg weight and higher egg laying intensity compared to B/B and A/A genotypes. No significant association was observed between IGFI genotypes and other production traits including egg weight, weight of sexual maturity and body weight. These results suggest that there is a possibility of $I G F I$ genotypes acting as a genetic marker for selecting some egg production traits in native chickens.
\end{abstract}

Key words: chicken, IGFI, Iran, production traits

\section{INTRODUCTION}

Preserving native breeds is an essential concern for conservation of domestic animal genetic resources. Native breeds are usually small-size with low productivity, but have specific characteristics such as resistance to different diseases as a 
Allelic polymorphism of insulin-like growth factor I gene and its association with production traits ...

result of exposure to pathogens and adaptation to the environment (Schou et al., 2010; Chang et al., 2011).

Production traits are multifactorial and controlled by the additive effects of multiple genes. Furthermore, health events and environmental factors could also influence these phenotypic traits (Li et al., 2010; Bulut et al., 2013). Nevertheless, the candidate gene approach could be used as a powerful method for evaluating the effect of contributing genes which are involved in the expression of quantitative differences between individuals in the population (Kwon \& Goate 2000; Nagaraja et al., 2000).

Candidate genes that are extensively studied in chickens are those of the growth hormone axis, because of the wide range of biochemical and physiological processes that they regulate. This axis mainly comprises growth hormone (GH), growth hormone releasing factor (GRF), $\mathrm{GH}$ receptor, insulin-like growth factor-I (IGFI) and insulin-like growth factor-II (IGFII) (Feng et al., 1997).

IGFI is a single chain polypeptide comprising 70 amino acid residues, with three intra chain disulfide bridges. IGFI is an essential regulator of cell proliferation and differentiation, DNA/protein synthesis and growth stimulation in different species. It is associated with several phenotypic features in chicken including production and reproduction traits. IGFI gene could be linked to the quantitative trait loci (QTL) that control egg production, egg quality, body weight and reproductive traits in chicken (Nagaraja et al., 2000; Kim et al., 2004; Li et al., 2010; Tang et $a l ., 2010)$. The purpose of this study was to evaluate the IGFI gene polymorphism and its association to production traits (body weight, egg production and sexual maturity) in Iranian native chickens.

\section{MATERIALS AND METHODS}

\section{Experimental birds}

Three hundred and thirteen whole blood samples were collected from the Native poultry breeding center, Khorasan province, Iran. Blood samples were taken from the ulnar vein and stored in vacuum tubes containing EDTA at $-20{ }^{\circ} \mathrm{C}$ before examination. This population has been under selective breeding to improve egg production traits for nine generations. Twelve production traits measurements were recorded for each birds including: body weight at 1 day of age (BW1), body weight at 8 weeks of age (BW8), body weight at 12 weeks of age (BW12), first egg weight (EW1), average egg weight at 28,30 and 32 weeks of age (EW 28, EW30, EW32), average egg weight during the 84-day recording period (EW84), total egg number laid during the 84-day recording (EGGNO), egg laying intensity (EL-Inten), age and weight of sexual maturity (ASM, WSM). All applicable national and institutional guidelines for the care and use of animals were followed. Genomic DNA was extracted from whole blood using DNA Extraction Kit (Bioneer, Korea) and checked with spectrophotometry and electrophoresis.

\section{PCR amplifications and genotyping of IGFI}

A $621 \mathrm{bp}$ fragment of 5' untranslated region (5'-UTR) of the IGFI gene was amplified using forward 5'-GACTATACA GAAAGAACCCAC-3' and reverse 5'TCACTCAAGTGGCTCAAGGT-3' primers. The PCR reaction was carried out in a final volume of $25 \mu \mathrm{L}$ containing: $50 \mathrm{ng}$ of template DNA, $2 \mathrm{mM} \mathrm{MgCl} 2,10 \mu \mathrm{M}$ of each primer and $1 \mathrm{U}$ Taq DNA polymerase (Fermentas, Germany). The applied cycles were denaturation at $94{ }^{\circ} \mathrm{C}$ 
for $5 \mathrm{~min}$, followed by 35 cycles of $45 \mathrm{~s}$ at $94{ }^{\circ} \mathrm{C}, 45 \mathrm{~s}$ at $57{ }^{\circ} \mathrm{C}, 60 \mathrm{~s}$ at $72{ }^{\circ} \mathrm{C}$, and final synthesis at $72{ }^{\circ} \mathrm{C}$ for $10 \mathrm{~min}$ (Nagaraja et al., 2000).

Single nucleotide polymorphism of the IGFI gene was identified by polymerase chain reaction- restriction fragment length polymorphism (PCR-RFLP) and PstI restriction endonuclease enzyme. As a final point, the IGFI SNP was confirmed by direct sequencing of each allele (ABI 3130 DNA sequencer, Applied Biosystems, Foster City, CA, USA).

\section{Population genetic/statistical analysis}

The observed $(\mathrm{Na})$ and effective $(\mathrm{Ne})$ allele numbers, genotype and allele frequencies, observed and expected heterozygosity (Ho and $\mathrm{He}$, respectively) were estimated using POPGENE software version 1.32.0 (Levene, 1949; Yeh et al., 1997). Genetic diversity was also measured by unbiased expected heterozygosity and number of alleles (Nei, 1973). Deviation from Hardy-Weinberg equilibrium (HWE) was also estimated using Fisher's exact test (Guo \& Thompson, 1992).

Association between IGFI alleles and production traits including body weight (BW1, BW8 and BW12), egg weight (EW1, EW 28, EW30, EW32 and EW84), total egg number (EGGNO), age and weight of sexual maturity (ASM, WSM) and egg laying intensity (EL-Inten) were analysed using the following model:

$$
\mathrm{Y}_{\mathrm{i}}=\mu+\Sigma \mathrm{b}_{\mathrm{j}} \mathrm{f}_{\mathrm{ij}}+\varepsilon_{\mathrm{i}}
$$

where $\mathrm{Y}_{\mathrm{i}}$ : the dependent variable for specific trait in $i^{\text {th }}$ chicken, $\mu$ : a general mean, $\mathrm{f}_{\mathrm{ij}}$ : the copy number of the IGFI: $\mathrm{j}^{\text {th }}$ allele in the $i^{\text {th }}$ chicken; $b_{j}$ : half the substitution effect for the $I G F I \mathrm{j}^{\text {th }}$ allele; and $\varepsilon_{\mathrm{i}}$ : the residual effect for the $i^{\text {th }}$ chicken with variance. For each allele, all individuals were considered as either non-carrier (0) or carrier (1) and then single band analysis was performed to determine the coefficient effect of each allele on each phenotype. The most frequent allele was considered as reference and the association study was evaluated using multivariate regression analysis and GLM procedures (SPSS v. 21).

\section{RESULTS}

The PCR-RFLP analysis with PstI enzyme revealed two alleles $\mathrm{A}$ (PstI -) and $\mathrm{B}$ $($ PstI + ) and three genotypes: $\mathrm{A} / \mathrm{A}$ $(621 \mathrm{bp}), \mathrm{A} / \mathrm{B}(621+257+364)$ and $\mathrm{B} / \mathrm{B}$ $(257+364)$ in 621 bp fragment of $I G F I$ 5'-UTR (Fig. 1). Allele B and genotype $\mathrm{A} / \mathrm{B}$ had the highest frequency in this population $(60.1 \%$ and $61.98 \%$ respectively).

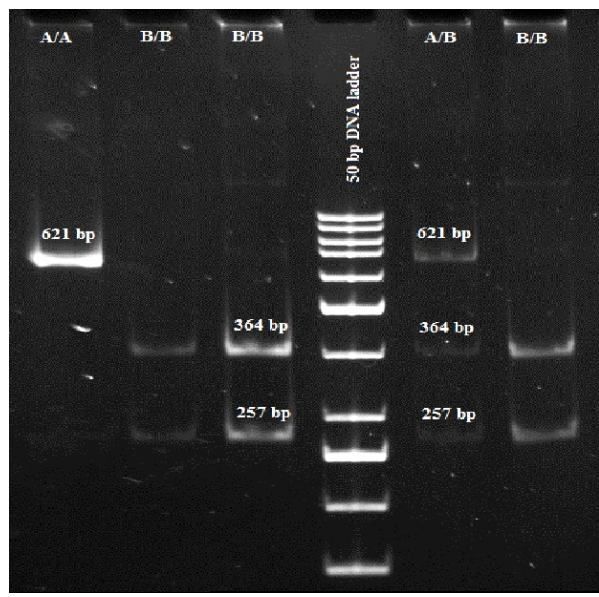

Fig. 1. PCR-RFLP pattern for 5'UTR of $I G F I$ with PstI digestion on $10 \%$ polyacrylamide gel.

The allele and genotypic frequencies of IGFI-PstI are summarised in Table 1. Sequence analysis of three genotypes showed a C/T substitution at position 257 , resulting in these polymorphisms. High 
level of heterozygosity (62\%) and deviation from Hardy-Weinberg equilibrium $(\mathrm{P}<0.0001)$ was also observed in this locus (Table 2).

Table 1. Genotype and allele frequency of IGFI-PstI in Iranian native chicken

\begin{tabular}{lcc}
\hline $\begin{array}{l}\text { Allele fre- } \\
\text { quency (\%) }\end{array}$ & $\begin{array}{c}\text { Genotype fre- } \\
\text { quency (\%) }\end{array}$ & Genotype \\
\hline $\mathrm{A}=39.9$ & 8.95 & $\mathrm{~A} / \mathrm{A}$ \\
$\mathrm{B}=60.1$ & 61.98 & $\mathrm{~A} / \mathrm{B}$ \\
& 29.07 & $\mathrm{~B} / \mathrm{B}$ \\
\hline
\end{tabular}

Table 2. Observed and expected heterozygosity and hemozygosity in Iranian native chicken

\begin{tabular}{lc}
\hline Locus & IGFI \\
\hline Sample size & 626 \\
$\mathrm{Na}$ & 2 \\
$\mathrm{Ne}$ & 1.9245 \\
Obs_Hom & 0.3770 \\
Obs_Het & 0.6198 \\
Exp_Hom & 0.5188 \\
Exp_Het & 0.4812 \\
HWE P-value & 0.0000 \\
Nei & 0.4804 \\
\hline
\end{tabular}

$\mathrm{Na}=$ observed number of alleles; $\mathrm{Ne}=$ effective number of alleles; Obs_Hom $=$ observed homozygosity; Obs_Het=observed heterozygosity; Exp_Hom=expected homozygosity; Exp_Het =expected heterozygosity; Nei=expected heterozygosity as per Nei (1973). Expected homozygosity and heterozygosity were computed as per Levene (1949).

In association study, allele B was the most frequent allele and considered as a reference. Therefore, $\mathrm{A} / \mathrm{A}$ and $\mathrm{A} / \mathrm{B}$ genotypes were compared with $\mathrm{B} / \mathrm{B}$ genotype for different production traits. The $\mathrm{A} / \mathrm{B}$ genotype was significantly correlated with higher egg laying intensity (EL-Inten) $(\mathrm{P}=0.016)$ and lower first egg weight (EW1) $(\mathrm{P}=0.05)$. No significant associa- tion was found between IGFI genotypes and body weight at 1 day of age (BW1), body weight at 8 weeks of age (BW8), body weight at 12 weeks of age (BW12), average egg weight at 28, 30 and 32 weeks of age (EW 28, EW30, EW32), average egg weight during the 84-day recording period (EW84), total egg number laid for the 84-day recording period (EGGNO), age and weight of sexual maturity (ASM, WSM) $(\mathrm{P}>0.05)$ (Table 3$)$.

\section{DISCUSSION}

Genetic diversity in chickens has evolved during domestication, selection for phenotypic traits, development of high productive breeds and interaction between host and pathogens (Weigend \& Romanov, 2001; Izadi et al., 2011). Selection based on the genetic factors has been considered as a practical approach for improving animal's production in recent breeding strategies. Linkage between a genetic marker and quantitative trait locus (QTLs) associated with special phenotypic trait could be used in marker assisted selection (MAS) programme. Based on it, genetic markers which are closely linked to these QTLs can be used in order to select and improve a special trait with high heritability (Chatterjee et al., 2010; Bulut et al., 2013).

Because of the important roles of insulin-like growth factors (IGFI and IGFII) in growth regulation and stimulation, these factors are considered as one of the most important candidate genes for controlling phenotypic traits (production and reproduction) in chickens (Nagaraja et al., 2000; Kim et al., 2004; Tang et al., 2010).

IGFI is located on chromosome 1 within a linkage region where some QTLs controlling growth have been detected (Chatterjee et al., 2010; Bulut et al., 
Table 3. Association of IGF1 genotypes with production traits in Iranian native chicken (vs the reference genotype $\mathrm{B} / \mathrm{B})$.

\begin{tabular}{lccrrr}
\hline $\begin{array}{l}\text { Production } \\
\text { traits }\end{array}$ & $\begin{array}{c}\text { Overall } \\
\text { mean }\end{array}$ & $\begin{array}{c}I G F 1 \text { geno- } \\
\text { types }\end{array}$ & $\begin{array}{c}\text { Allele } \\
\text { effect }\end{array}$ & $\begin{array}{c}\text { Standard } \\
\text { error }\end{array}$ & $\begin{array}{c}\text { P } \\
\text { value }\end{array}$ \\
\hline EW1 (g) & $40.59 \pm 7.3$ & $\mathrm{~A} / \mathrm{A}$ & -0.563 & 5.98 & 0.926 \\
& & $\mathrm{~A} / \mathrm{B}$ & -4.31 & 2.22 & 0.050 \\
\hline EW28 (g) & $48.75 \pm 3.9$ & $\mathrm{~A} / \mathrm{A}$ & 5.82 & 6.62 & 0.39 \\
& & $\mathrm{~A} / \mathrm{B}$ & -2.32 & 2.46 & 0.35 \\
\hline EW30 (g) & $49.66 \pm 3.95$ & $\mathrm{~A} / \mathrm{A}$ & 5.75 & 8.16 & 0.49 \\
& & $\mathrm{~A} / \mathrm{B}$ & -0.30 & 3.04 & 0.92 \\
\hline EW32 (g) & $50.90 \pm 3.66$ & $\mathrm{~A} / \mathrm{A}$ & 6.63 & 6.05 & 0.28 \\
& & $\mathrm{~A} / \mathrm{B}$ & -1.68 & 2.25 & 0.46 \\
\hline EW84 (g) & $48.16 \pm 3.6$ & $\mathrm{~A} / \mathrm{A}$ & 0.46 & 5.25 & 0.93 \\
& & $\mathrm{~A} / \mathrm{B}$ & -0.76 & 1.95 & 0.70 \\
\hline EGGNO & $48.74 \pm 14.91$ & $\mathrm{~A} / \mathrm{A}$ & 10.23 & 11.71 & 0.39 \\
& & $\mathrm{~A} / \mathrm{B}$ & 4.98 & 4.36 & 0.27 \\
\hline EL-Inten (\%) & $69.24 \pm 17.5$ & $\mathrm{~A} / \mathrm{A}$ & 13.07 & 9.38 & 0.18 \\
& & $\mathrm{~A} / \mathrm{B}$ & 9.37 & 3.49 & 0.016 \\
\hline ASM (days) & $157.76 \pm 11.5$ & $\mathrm{~A} / \mathrm{A}$ & 7.46 & 12.85 & 0.56 \\
& & $\mathrm{~A} / \mathrm{B}$ & 1.70 & 6.39 & 0.79 \\
\hline WSM (g) & $1762.80 \pm 175.9$ & $\mathrm{~A} / \mathrm{A}$ & 31.47 & 182.38 & 0.86 \\
& & $\mathrm{~A} / \mathrm{B}$ & 122.84 & 90.79 & 0.18 \\
\hline BW1 (g) & $35.80 \pm 3.8$ & $\mathrm{~A} / \mathrm{A}$ & 2.49 & 2.57 & 0.33 \\
& & $\mathrm{~A} / \mathrm{B}$ & 0.78 & 1.17 & 0.50 \\
\hline BW8 (g) & $680.62 \pm 134.3$ & $\mathrm{~A} / \mathrm{A}$ & 74.06 & 74.09 & 0.32 \\
& & $\mathrm{~A} / \mathrm{B}$ & 43.38 & 33.78 & 0.20 \\
\hline BW12 (g) & $1284.25 \pm 246.3$ & $\mathrm{~A} / \mathrm{A}$ & -61.77 & 140.26 & 0.66 \\
& & $\mathrm{~A} / \mathrm{B}$ & 8.95 & 63.94 & 0.88 \\
\hline
\end{tabular}

EW1: first egg weight; EW28; EW30; EW32: average egg weight at 28, 30, 32 weeks of age; EW84: average egg weight during the 84-day recording period, EGGNO: total egg number laid during the 84-day recording period, EL-Inten: egg laying intensity, ASM, WSM: age and weight of sexual maturity; BW1, BW8, BW12: body weight at 1 day, 8 weeks, 12 weeks of age.

2013). Several studies have shown that SNP within the 5' flanking region of IGFI (the promoter region), is significantly associated with body weight, egg production, egg shell weight and quality (Lei et al., 2005; Tang et al., 2010).

In the present study, the PstI-digested PCR products of the IGFI gene revealed polymorphic fragments $(257,364$, and $621 \mathrm{bp}$ ), which was inconsistent with the first report by Nagaraja et al. (2000). The results of the allele and genotype frequency for the IGFI gene in native Iranian population were in close agreement with Silkies Chinese native breed and Mazandaran native chickens (another Iranian native breed), but somewhat different from that reported for Korean native Ogal chickens (KNOC) (Kim et al., 2004; Tang et al., 2010; Abbasi \& Kazemi, 2011).

The association of IGFI B/B genotype with higher egg weight in the Iranian native population was in great agreement with white Leghorn chicken (Nagaraja et al., 2000). No genetic association of IGFI alleles with body weight and age of sexual 
maturity were found, neither in Iranian nor in Leghorns population. Association of $\mathrm{B} / \mathrm{B}$ genotype with higher egg production has also been reported for Korean native Ogal chickens. The results of this research showed that allele B was associated with a higher expression of IGFII in ovarian follicles. So, B/B genotype could be a regulatory factor of follicular development and egg production in Korean native chickens (Kim et al., 2004). Tang et al. (2010) studied the association between IGFI gene polymorphism and body weight, age of sexual maturity, egg weight and number in two Chinese (Beijing and Silkies) populations. The A/B genotype and A allele were significantly associated with higher BW8, BW10 and BW13 than B/B in Silkies population (Kim et al., 2004; Tang et al., 2010). The different population genetic backgrounds, selection intensity and breeding aims might be the main causes for such differences across the populations.

In conclusion, SNP in IGFI locus was significantly associated with egg laying intensity (EL-Inten) and first egg weight (EW1) in the Iranian native population. Based on these results, IGFI gene could be considered as a genetic marker for selecting and improving quantitative traits in local chicken. These data would be beneficial for breed conservation and improvement of phenotypic traits.

\section{REFERENCES}

Abbasi, H. A. \& M. Kazemi, 2011. Detection of polymorphism at the insulin like growth factor-i gene in Mazandaran native chicken using polymerase chain reactionrestriction fragment length polymorphism method. American Journal of Animal and Veterinary Sciences, 6, 80-83.

Bulut, Z., E. Kurar, Y. Ozsensoy, M. Nizamlioglu, M. Garip, A. Yilmaz, T. Caglayan,
S. Dere, V. Kurtoglu \& M. Dogan, 2013. Determination of chromosomal regions affecting body weight and egg production in Denizli $\times$ White Leghorn F2 populations. Eurasian Journal of Veterinary Sciences, 29, 30-38.

Chang, C. S., C. F. Chen, C. BerthoulySalazar, O. Chazara, Y. P. Lee, C. M. Chang, K. H. Chang, B. Bedhom \& M. Tixier-Boichard, 2011. A global analysis of molecular markers and phenotypic traits in local chicken breeds in Taiwan. Animal Genetics, 43, 172-182.

Chatterjee, R., R. P. Sharma, T. K. Bhattacharya, M. Niranjan \& B. L. Reddy, 2010. Microsatellite variability and its relationship with growth, egg production, and immunocompetence traits in chickens. Biochemical Genetics, 48, 71-82.

Feng, X. P., U. Kuhnlein, S. E. Aggrey, J. S. Gavora \& O. Zadworny, 1997. Trait association of genetic markers in the growth hormone and growth hormone receptor genes in a white leghorn strain. Poultry Science, 76, 1770-1775.

Guo, S. W. \& E. A. Thompson, 1992. Performing the exact test of Hardy-Weinberg proportion for multiple alleles. Biometrics, 48, 361-372.

Izadi, F., C. Ritland \& K. M. Cheng, 2011. Genetic diversity of the major histocompatibility complex region in commercial and noncommercial chicken flocks using the LEI0258 microsatellite marker. Poultry Science, 90, 2711-2717.

Kim, M. H., D. S. Seo \& Y. Ko, 2004. Relationship between egg productivity and insulin-like growth factor-I genotypes in Korean native Ogol chickens. Poultry Science, 83, 1203-1208.

Kwon, J. M. \& A. M. Goate, 2000. The candidate gene approach. Alcohol Research and Health, 24, 164-168.

Lei, M., Q. Nie, X. Peng, D. Zhang \& X. Zhang, 2005. Single nucleotide polymorphisms of the chicken insulin-like factor binding protein 2 gene associated with 
chicken growth and carcass traits. Poultry Science, 84, 1191-1198.

Levene, H., 1949. On a matching problem arising in genetics. Annals of Mathematical Statistics, 20, 91-94.

Li, H., W. Zhu, K. Chen, W. Song, J. Shu \& W. Han, 2010. Effect of the polymorphism of GHR gene and IGF-I gene on egg quality in wenchang chicken. Research Journal of Poultry Science, 3, 19-22.

Nagaraja, S. C., S. E. Aggrey, J. Yao, D, Zadworny, R. W. Fairfull \& U. Kuhnlein, 2000. Trait association of a genetic marker near the IGFI gene in egg-laying chickens. Journal of Heredity, 91, 150-156.

Nei, M., 1973. Analysis of gene diversity in subdivided populations. Proceedings of the National Academy of Sciences of the United States of America, 70, 3321-3323.

Schou, T. W., R. Labouriau, A. Permin, J. P. Christensen, P. Sorensen, H. P. Cu, V. K. Nguyen \& H. R. Juul-Madsen, 2010. MHC haplotype and susceptibility to experimental infections (Salmonella Enteritidis, Pasteurella multocida or Ascaridia galli) in a commercial and an indigenous chicken breed. Veterinary Immunology and Immunopathology, 135, 52-63.

Tang, S., D. Sun, J. Ou, Y. Zhang, G. Xu \& Y. Zhang, 2010. Evaluation of the IGFs (IGF1 and IGF2) genes as candidates for growth, body measurement, carcass, and reproduction traits in Beijing You and
Silkie chickens. Animal Biotechnology, 21, 104-113.

Weigend, S. \& M. N. Romanov, 2001. Current strategies for the assessment and evaluation of genetic diversity in chicken resources. World's Poultry Science Journal, 57, 275-288.

Yeh, F. C., R. C. Yang, T. B. J. Boyle \& J. X. Mao, 1997. POPGENE: Software Microsoft Windows based freeware for population genetic analysis vol version 1.32 . Center for International Forestry Research, Univ Alberta, Edmonton, Canada.

Paper received 16.10.2016; accepted for publication 25.11.2016

\section{Correspondence:}

Dr. Atefeh Esmailnejad

Assistant Professor of Immunology

Department of Pathobiology,

School of Veterinary Medicine,

Shiraz University, Shiraz, Iran

Telephone: +98 7136138690

Fax: +98 7132286940

e-mail: Esmailnejad82@gmail.com 